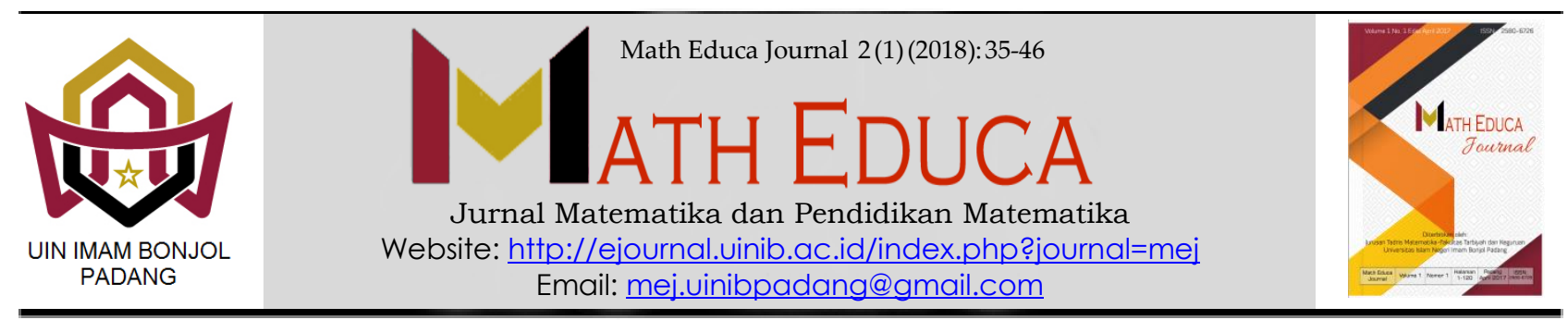

\title{
PENERAPAN PEMBELAJARAN INKUIRI TERBIMBING DENGAN PENDEKATAN CONCRETE-REPRESENTATIONAL-ABSTRACT TERHADAP ADVERSITY QUOTIENT SISWA SMP
}

\author{
Lisa Dwi Afri \\ Pendidikan Matematika, IlmuTarbiyah dan Keguruan, UIN Sumatera Utara Medan \\ Email: lisadwiafri@uinsu.ac.id
}

Received: January 2018; Accepted: March 2018; Published: April 2018

\begin{abstract}
Abstrak
Penelitian ini dilatarbelakangi oleh pentingnya mengembangkan suatu kecerdasan emosional dalam menghadapi masalah matematis yaitu adversity quotient (AQ) siswa. Penelitian ini mengkaji tentang perbedaan adversity quotient matematis antara siswa yang memperoleh pembelajaran Inkuiri Terbimbing dengan pendekatan Concrete-Representational-Abstract (ITCRA) dengan siswa yang memperoleh pembelajaran konvensional. Penelitian ini merupakan penelitian quasi experiment dengan desain non-equivalent control group design. Populasi penelitian adalah siswa kelas VIII SMP Negeri 1 Padang Panjang yang terdaftar pada Tahun Pelajaran 2014/2015. Sampel yang digunakan adalah dua kelas dari tujuh kelas yang ada. Instrumen yang digunakan untuk mengumpulkan data berupa skala adversity quotient matematis dan pedoman wawancara. Data yang diperoleh dianalisis menggunakan uji perbedaan rataan yaitu uji-t. Hasil penelitian menunjukkan bahwa terdapat perbedaan adversity quotient matematis siswa yang memperoleh pembelajaran ITCRA dengan siswa yang memperoleh pembelajaran konvensional.
\end{abstract}

Kata kunci : Inkuiri Terbimbing, Concrete-Representational-Abstract, Adversity Quotient.

\begin{abstract}
This research is motivated by the importance of developing students's adversity quotient (AQ). This research examines the difference of students's $A Q$ in Guided Inquiry learning with Concrete-Representational-Abstract approach (ITCRA) and students's AQ in conventional learning. This research is quasi experiment with nonequivalent control group design. The population is students which grade eighth in SMPN 1 Padang Panjang, and the samples is selected two classes from seven existing classes. Instruments used to collect data is scale of adversity quotient dan intervies guidelines. Data obtained were analyzed using mean difference t-test. The results show that there are differences of student's $A Q$ getting ITCRA learning and student's AQ getting conventional learning.
\end{abstract}

Keywords: Guided Inquiry, Concrete-Representational-Abstract, Adversity Quotient.

Peer review under responsibility UIN Imam Bonjol Padang.

(C) 2018 UIN Imam Bonjol Padang. All rights reserved.

p-ISSN: 2580-6726

e-ISSN: 2598-2133 


\section{PENDAHULUAN}

Kesuksesan yang ingin dicapai oleh setiap orang, pada mulanya dipercaya penentunya adalah Intelegensi Qoutient (IQ), yaitu sebuah konsep kecerdasan yang terukur secara ilmiah dan dipengaruhi oleh keturunan. Namun ternyata tidak semua orang yang memiliki IQ tinggi mampu mencapai sukses (Stoltz, 2003). Banyak contoh dalam kehidupan ini orang yang memiliki IQ tinggi tetapi tidak mewujudkan potensinya, bahkan mengalami kegagalan dalam hidupnya. Sementara banyak yang lainnya dengan IQ yang sedang-sedang saja bisa berkembang pesat (Goleman dalam Stoltz, 2000).

Goleman (stoltz., 2000) menyatakan bahwa EQ lebih penting dari pada IQ. Namun, seperti halnya IQ, tidak setiap orang memanfaatkan EQ dan potensi mereka sepenuhnya, meskipun kecakapan-kecakapan yang berharga itu mereka miliki. Karena EQ tidak mempunyai tolak ukur yang sah dan metode yang jelas untuk mempelajarinya, maka kecerdasan emosional tetap sulit dipahami. Sejumlah orang memiliki IQ yang tinggi dan memiliki segala aspek kecerdasan emosional, namun mereka gagal menunjukkan kemampuannya.

Berdasarkan hal tersebut, bukan IQ ataupun EQ yang menentukan suksesnya seseorang, tetapi keduanya memainkan suatu peran. Terdapat orang yang mampu bertahan, sementara yang lainnya yang mungkin sama-sama brilian dan pandai bergaul gagal ataupun menyerah. Hal tersebut dipengaruhi oleh suatu kecerdasan selain IQ dan EQ, yaitu Adversity Quotient (AQ).

Stoltz (2000) menyatakan bahwa AQ merupakan kemampuan individu untuk dapat bertahan dalam menghadapi segala macam kesulitan sampai menemukan jalan keluar, memecahkan berbagai macam permasalahan, mereduksi hambatan dan rintangan dengan mengubah cara berpikir dan sikap terhadap kesulitan tersebut. Kesuksesan sangat dipengaruhi dan diramalkan melalui cara seseorang merespon kesulitan yang datang, menjelaskan kesulitan yang timbul, dan mengatasi kesulitan tersebut. AQ sering dijadikan ukuran kemampuan seseorang untuk mengatasi kesulitan.

AQ yang dimiliki seseorang lebih signifikan daripada IQ, pendidikan dan keterampilan sosial. Seseorang yang memiliki AQ yang tinggi dapat mencapai kesuksesan dalam hidup karena mereka mampu bertahan saat menghadapi kesulitan ataupun hambatan dalam proses mencapai kesuksesan sampai mereka memperoleh kesuksesan tersebut, sedangkan seseorang yang memiliki AQ rendah gampang menyerah.

Dunia pendidikan berusaha mengembangkan AQ siswa melalui pembelajaran di sekolah, diantaranya dengan menerapkan Kurikulum 2013 yang bernuansa pembelajaran yang berbasis masalah. Hal ini bertujuan agar siswa terbiasa dalam menghadapi masalah dan memecahkannya. Selanjutnya, keterampilan memecahkan masalah tersebut diharapkan dapat diintegrasikan siswa pada kehidupannya seharihari.

Menghadapi hambatan atau kesulitan dalam memecahkan masalah saat proses pembelajaran, siswa perlu dibekali dengan kemampuan mempengaruhi pola pikir dan emosinya sehingga tidak mudah menyerah dalam menyelesaikan 
masalah tersebut dan memperoleh prestasi dalam pembelajaran. Dengan kata lain, siswa tidak menghindar dari tugas-tugas yang sulit, tidak cepat menyerah, dan tetap optimis menemukan solusi dari masalah. Sebagaimana yang dinyatakan oleh Dahlan \& Dadang (2011), pemecahan masalah membutuhkan sikap-sikap mental yang harus diidentifikasikan, dikuasai, dan diinternalisasi oleh siswa untuk menjadi pemecah soal yang berhasil. Keberhasilan siswa dalam memecahkan masalah dipengaruhi oleh cara siswa merespon kesulitan yang dihadapi saat mencari solusi dari masalah tersebut. Kemampuan individu dalam menghadapi kesulitan ini disebut adversity quotient (AQ).

Leman (Khaerunnisa, 2013) menyatakan bahwa kemampuan memecahkan masalah, daya tahan menghadapi masalah, dan keberanian mengambil resiko merupakan salah satu faktor yang mempengaruhi kesuksesan. Siswa harus belajar tetap teguh dalam menghadapi penolakan berulang dan fleksibel dalam memilih strategistrategi penyelesaian. Seseorang yang mempunyai daya tahan yang kuat baik tekanan fisik, maupun mental akan mengantarkan seseorang untuk mencurahkan segala kemampuan, potensi agar permasalahan tersebut bisa diatasi. Sebaliknya, individu yang mempunyai daya tahan yang rendah akan merespon kesulitan sebagai hal yang bersifat menetap, tidak dapat diubah sehingga melahirkan sikap ketidakberdayaan.

AQ dapat membantu individu memperkuat kemampuan, pekerja keras, keuletan, tanggung jawab dan ketekunan dalam menghadapi tantangan hidup sehari-hari dengan tetap berpegang pada prinsip-prinsip dan impian.
Semakin tinggi AQ, semakin besar kemungkinan seseorang untuk bersikap optimis dan inovatif dalam mengatasi kesulitan serta bertanggung jawab untuk menyelesaikan masalah. Mereka tidak mudah mengeluh dan tidak mudah berputus asa walau kondisi seburuk apapun. Sebaliknya semakin rendah tingkat AQ seseorang, maka semakin mudah seseorang untuk menyerah, menghindari tantangan dan mengalami stress serta mengeluh sepanjang hari ketika menghadapi persoalan dan sulit untuk melihat secara positif dibalik semua permasalahan yang dihadapinya.

Pada saat pembelajaran, siswa dituntut untuk mengerahkan kemampuan pemecahan masalah dan siswa penting untuk memiliki AQ (adversity quotient) dalam menghadapi kesulitan dan hambatan yang sewaktu-waktu muncul. Berdasarkan studi pendahuluan yang dilakukan penulis pada bulan Agustus 2014, menunjukkan bahwa kemampuan sebagian besar siswa dalam mengontrol diri saat menghadapi masalah atau kesulitan dalam pelajaran matematika masih perlu untuk diperhatikan dan ditingkatkan. Berdasarkan pengakuan yang diperoleh dari beberapa orang siswa, ketika menghadapi kesulitan dalam pembelajaran matematika mereka cenderung merasa malas dan pesimis. Kesulitan yang dialami bukannya mendorong mereka untuk bertanya pada sumber lain seperti temannya yang lebih paham ataupun guru yang bersangkutan, mereka lebih memilih untuk menunggu pekerjaan teman dan menyalinnya.

Pada penelitian yang dilakukan Sakrani (2014) juga ditemukan bahwa terdapat beberapa siswa cenderung berhenti saat merasa tidak akan menemukan solusi akhir dari suatu masalah yang diberikan dikarenakan menganggap masalah itu 
di luar kemampuannya. Hal ini mengindikasikan masih perlunya usaha untuk meningkatkan kemampuan adversity quotient matematis siswa.

Tuntutan dari permasalahan yang telah diungkapkan, diperlukan suatu pembelajaran yang dapat memfasilitasi siswa untuk berperan aktif, menarik dan menantang siswa memecahkan masalah, serta dapat mengembangkan kemampuan adversity quotient (AQ) siswa. Model pembelajaran inkuiri merupakan salah satu pembelajaran yang ditujukan agar siswa senantiasa mampu memecahkan masalah (Abidin, 2014, Matthew \& Kenneth, 2013). Model ini menerapkan pendekatan konstruktivis dan menekankan pada proses berpikir untuk memecahkan masalah (Trianto, 2007).

Pembelajaran inkuiri diawali dengan aktivitas merumuskan masalah dan hipotesis, kemudian siswa mencari informasi, data, fakta yang diperlukan untuk memeriksa hipotesis, selanjutnya menarik kesimpulan dan generalisasi, serta mengaplikasikan kesimpulan generalisasi tersebut dalam situasi baru (Ruseffendi, 1991). Pembelajaran inkuiri ini memberikan kesempatan kepada siswa untuk mengembangkan ide-ide matematikanya dan menerapkan strategi pemecahan masalah sendiri, dan hal ini dapat meningkatkan kemampuan pemecahan masalah siswa (O’Connor, 2004).

Namun, mengingat siswa masih memerlukan konsep dasar untuk menemukan sesuatu, serta siswa juga belum terbiasa dengan pembelajaran dengan model pembelajaran inkuiri, maka model inkuiri yang akan digunakan adalah model pembelajaran inkuiri terbimbing. Model ini merupakan model pembelajaran inkuiri dimana guru membimbing siswa melakukan kegiatan dengan memberi pertanyaan awal dan mengarahkan pada suatu diskusi.

Effendi (2012) dalam penelitiannya pada siswa SMP mengatakan bahwa siswa masih merasa bingung dalam mengembangkan pikiran saat berhadapan dengan hal-hal abstrak. Hal ini dikarenakan perkembangan kognitif siswa SMP berada pada masa awal transisi antara berpikir konkret ke berpikir abstrak, sehingga proses berpikir abstrak siswa belum bisa maksimal (Suparno, 2001). Sumarmo (2004) menambahkan bahwa perkembangan kognitif siswa SMP sebagian besar masih berada pada tahap operasi konkret, sehingga diperlukan contoh-contoh nyata untuk membangun pemahaman matematika siswa. Oleh karena itu, masih diperlukan suatu pendekatan pembelajaran yang dapat menjembatani siswa dari berpikir konkret ke berpikir abstrak, salah satunya adalah pendekatan pembelajaran

Concrete-RepresentationalAbstract (CRA).

Pendekatan CRA ini terdiri dari tiga langkah yang saling berkaitan yaitu tahap concrete (konkret), tahap representational (representasi), dan tahap abstract (abstrak) (Witzel, 2005). Pada tahap konkret, siswa menemukan konsep melalui benda-benda manipulatif yang sebenarnya, dilanjutkan dengan tahap representasi dimana siswa belajar melalui representasi bergambar dari benda manipulatif yang digunakan pada tahap konkret, dan tahap abstrak siswa belajar dengan notasi abstrak seperti bilangan dan operasinya.

Witzel (2005) menyatakan bahwa CRA membantu siswa dalam memecahkan masalah 
matematika yang sulit dan bersifat abstrak. Hal ini sejalan dengan hasil penelitian Yuliawaty (2011), pendekatan CRA dapat meningkatkan kemampuan siswa untuk mengingat dan memilih prosedur yang tepat dalam pemecahan masalah. Kelebihan dari pendekatan CRA ini terletak pada intensitas dan kekonkretan yang membantu siswa mempertahankan kerangka kerja dalam memori kerja untuk menyelesaikan masalah (NCTM dalam Rahmawati, 2013). Di samping itu adanya tahap representasi, membiasakan siswa untuk menyusun representasi dalam memecahkan masalah. Guler \& Ciltas (2011) mengatakan siswa yang menggunakan representasi dalam pemecahan masalah akan lebih berhasil dan menjadikan siswa tidak merasa bosan dalam pembelajaran.

Berdasarkan pendapat dan uraian di atas, model pembelajaran Inkuri Terbimbing dengan pendekatan Concrete-Representational-Abstract (ITCRA) diduga berpotensi meningkatkan aspek psikologis siswa yaitu adversity quotient (AQ). Rifameutia (Hawadi, 2004) mengatakan pembelajaran yang dapat mengembangkan AQ siswa adalah pembelajaran yang memungkinkan siswa menerapkan langkah-langkah pemecahan masalah dan berkomunikasi melalui kegiatan yang menantang dan menarik bagi siswa. Hal ini dapat ditemukan pada pembelajaran ITCRA.

Di samping itu, Stoltz (2000) mengatakan bahwa pembelajaran yang dapat meningkatkan dan memperbaiki AQ siswa adalah pembelajaran yang memungkinkan siswa melakukan aktivitas listen, explore, analysis, and do. Artinya pembelajaran yang memberikan kesempatan siswa untuk saling berdiskusi dan berbagi pendapat dalam usaha memecahkan masalah, serta mengexplore dan menganalisis masalah yang diberikan, sehingga siswa dapat menentukan strategi saat menghadapi kesulitan. Pembelajaran ITCRA memberikan kesempatan kepada siswa untuk melakukan aktivitas-aktivitas tersebut.

Berdasarkan uraian di atas, penulis bermaksud melakukan penelitian dengan judul "Penerapan Pembelajaran Inkuiri Terbimbing dengan Pendekatan Concrete-RepresentationalAbstract terhadap Adversity Quotient Siswa SMP”.

\section{METODE PENELITIAN}

\section{Jenis Penelitian}

Penelitian ini merupakan penelitian kuantitatif yaitu kuasi eksperimen dengan nonequivalent control-group design.

\section{Waktu dan Tempat Penelitian}

Penelitian dilakukan di SMPN 1 Padang Panjang yang beralamat di Jl. Jendral Sudirman No.41, Padang Panjang, Sumatera Barat. Waktu pelaksanaan pada bulan Maret semester II Tahun Ajaran 2015/2016.

\section{Populasi dan Sampel}

Populasi pada penelitian ini adalah siswa kelas VIII di SMPN 1 Padang Panjang tahun ajaran 2014/2015 siswa kelas VIII-B SMPN 1 Padang Panjang tahun ajaran 2015/2016, sedangkan sampel dipilih secara purposive sampling dua kelas dari tujuh kelas yang ada yaitu kelas VIIIA sebagai kelas kontrol dan VIIIB sebagai kelas eksperimen. 
Data, Intrumen, dan Teknik Pengumpulan Data

Data penelitian terdiri dari data kuantitaif berupa skor dari skala Adversity Quotient (AQ), dan data kualitatif berupa hasil wawancara sebagai data untuk melengkapi hasil penyebaran skala AQ. Teknik pengumpulan data adalah penyebaran angket adversity quotient dan wawancara pada akhir program pembelajaran. Instrumen yang digunakan berupa skala adversity quotient dan pedoman wawancara.

\section{Teknik Analisis Data}

Data kuantitatif dianalisis dengan menggunakan uji perbedaan rataan yaitu uji-t, sedangkan data kualitatif dianalisis dengan cara dideskripsikan melengkapi data hasil penyebaran angket adversity quotient.

\section{HASIL PENELITIAN DAN PEMBAHASAN}

Berikut ini merupakan rangkuman skor adversity quotient matematis siswa pada kelas ITCRA dan kelas konvensional.

Tabel 1. Deskripsi Skor Adversity Quotient

\begin{tabular}{|c|c|c|c|c|c|}
\hline Pembelajaran & $\mathrm{N}$ & Min. & Max. & $\bar{x}$ & $\mathrm{sd}$ \\
\hline ITCRA & 32 & 68,52 & 108,49 & 87,85 & 9,42 \\
\hline Konvensional & 34 & 54,36 & 93,77 & 77,41 & 10,89 \\
\hline \multicolumn{6}{|c|}{ Skor maksimum ideal $=126,05$} \\
\hline
\end{tabular}

Pada Tabel 1 terlihat bahwa rataan skor adversity quotient matematis siswa kelas ITCRA sebesar 87,85 atau 69,69\% dari skor maksimum ideal dan untuk kelas konvensional sebesar 77,41 atau $61,41 \%$ dari skor maksimum ideal. Terlihat adanya perbedaan rataan skor adversity quotient matematis siswa pada kedua kelas sebesar 10,43 atau sebesar $8,28 \%$. Berikut hasil analisis skor AQ dengan menggunakan uji t.

Tabel 2. Hasil Uji Perbedaan Rataan Skor Adversity Quotient Matematis

\begin{tabular}{llccccc}
\hline Hasil & Kelas & $\mathrm{N}$ & $\mathrm{t}$ & $\mathrm{df}$ & $\begin{array}{c}\text { Sig. } \\
\text { (2-tailed) }\end{array}$ & Keputusan \\
\hline AQ & ITCRA & 32 & - & 64 & 0.000 & Tolak $_{0}$ \\
& Konvensional & 34 & 4,151 & & & \\
\hline
\end{tabular}

Berdasarkan Tabel 2 di atas, diperoleh nilai sig. (2-tailed) adalah 0,000, lebih kecil dari taraf signifikansi $\alpha=0,05$. Kesimpulan yang diperoleh adalah tolak $\mathrm{H}_{0}$, artinya adversity quotient matematis siswa kelas ITCRA yang memperoleh pembelajaran ITCRA berbeda secara signifikan dengan kelas konvensional yang memperoleh pembelajaran konvensional.

Hasil pengolahan data menunjukkan bahwa adversity quotient matematis siswa yang memperoleh pembelajaran inkuiri terbimbing dengan pendekatan concrete-representationalabstract (ITCRA) berbeda secara signifikan dengan adversity quotient matematis siswa yang memperoleh pembelajaran konvensional.

Berdasarkan aspek adversity quotient matematis yaitu

\section{C : Control (Kendali Diri)}

Kendali berkaitan dengan seberapa besar orang merasa mampu mengendalikan kesulitankesulitan yang dihadapinya dan sejauh mana individu merasakan bahwa kendali itu ikut berperan dalam peristiwa yang menimbulkan kesulitan. Semakin besar kendali yang dimiliki semakin besar kemungkinan seseorang untuk dapat bertahan menghadapi kesulitan dan tetap teguh dalam niat serta ulet dalam mencari penyelesaian. 
2. O2 : Origin (Asal Usul) dan Ownership (Pengakuan)

Kepemilikan atau dalam istilah lain disebut dengan asal-usul dan pengakuan akan mempertanyakan siapa atau apa yang menimbulkan kesulitan dan sejauh mana seseorang mengakui akibat-akibat kesulitan itu. Orang yang skor origin rendah akan cenderung berpikir bahwa semua kesulitan atau permasalahan yang datang itu karena kesalahan, kecerobohan, atau kebodohan dirinya sendiri serta membuat perasaan dan pikiran merusak semangatnya. Sebaliknya, semakin tinggi skor origin, semakin besar kecenderungan seseorang untuk menganggap sumber-sumber kesulitan itu berasal dari orang lain atau dari luar dan menempatkan perannya sendiri pada tempat yang sewajarnya.

Pada ownership seseorang akan mengakui akibat kesulitan yang dihadapinya sehingga akan timbul rasa tanggung jawab. Rasa bertanggung jawab ini memaksa seseorang untuk bertindak, membuat jauh lebih berdaya daripada yang mereka yang memiliki AQ rendah.

\section{E : Endurance (Daya Tahan)}

Dimensi ini lebih berkaitan dengan persepsi seseorang akan lama atau tidaknya kesulitan akan berlangsung. Daya tahan dapat menimbulkan penilaian tentang situasi yang baik atau buruk. Seseorang yang mempunyai daya tahan yang tinggi akan memiliki harapan dan sikap optimis dalam mengatasi kesulitan atau tantangan yang sedang dihadapi. Semakin tinggi daya tahan yang dimiliki oleh individu, makin besar kemungkinan seseorang dalam memandang kesuksesan sebagai suatu hal yang bersifat sementara dan orang yang mempunyai adversity quotient yang rendah akan menganggap bahwa kesulitan yang sedang dihadapi adalah sesuatu yang bersifat abadi, dan sulit untukdiperbaiki.

\section{R : Reach (Jangkauan)}

Jangkauan merupakan bagian dari AQ yang mempertanyakan sejauh manakah kesulitan akan menjangkau bagian lain dari individu. Reach juga berarti sejauh mana kesulitan yang ada akan menjangkau bagian-bagian lain dari kehidupan seseorang. Reach menunjukkan kemampuan dalam melakukan penilaian tentang beban kerja yang menimbulkan stress. Semakin tinggi jangkauan seseorang, semakin besar kemungkinannya dalam merespon kesulitan sebagai sesuatu yang spesifik dan terbatas. Semakin efektif dalam menahan atau membatasi jangkauan kesulitan, maka seseorang akan lebih berdaya dan perasaan putus asa atau kurang mampu membedakan hal-hal yang relevan dengan kesulitan yang ada, sehingga ketika memiliki masalah di satu bidang dia tidak harus merasa mengalami kesulitan untuk seluruh aspek kehidupan individu tersebut.

Berikut disajikan deskriptif rataan skor adversity quotient matematis ditinjau dari aspeknya.

Tabel 3. Statistik Deskriptif Skor Adversity Quotient Siswa Berdasarkan Aspek

\begin{tabular}{|c|c|c|c|c|c|c|}
\hline \multirow{2}{*}{$\begin{array}{l}\text { Pembelajar- } \\
\text { an }\end{array}$} & \multicolumn{5}{|c|}{$\begin{array}{c}\text { Aspek Adversity Quotient } \\
\text { Matematis }\end{array}$} & \multirow{2}{*}{$\begin{array}{l}\text { Rata- } \\
\text { an }\end{array}$} \\
\hline & $C$ & $O r$ & $O w$ & $R$ & $E$ & \\
\hline ITCRA & 24,73 & 16,05 & 24,71 & 9,26 & 13,10 & 87,85 \\
\hline Konvensional & 20,99 & 15,58 & 21,74 & 8,30 & 10,80 & 77,41 \\
\hline \multicolumn{7}{|l|}{ Skor } \\
\hline Maksimum & 34,37 & 24,99 & 37,16 & 13,18 & 16,34 & 126,05 \\
\hline Ideal & & & & & & \\
\hline
\end{tabular}


Berdasarkan Tabel 3, rataan kelas ITCRA pada aspek control/kendali yaitu sebesar 24,73 atau $71,96 \%$ dari skor maksimum ideal, sedangkan kelas konvensional 20,99 atau 61,09\% dari skor maksimum ideal 34,37. Terlihat perbedaan sebesar 3,74 atau $10,88 \%$. Hal ini menunjukkan bahwa adversity quotient matematis pada aspek control siswa kelas ITCRA lebih baik daripada kelas konvensional. Artinya kemampuan siswa kelas ITCRA untuk mengendalikan kesulitan-kesulitan dalam pembelajaran matematika lebih baik daripada siswa kelas konvensional.

Dari pengamatan selama pembelajaran, respon siswa saat menerima soal-soal yang diberikan tampak antusias dan memperlihatkan rasa keingintahuan, mereka tidak menghindari soal-soal yang diberikan guru. Siswa berusaha menyelesaikan masalah yang diberikan dengan diskusi dengan teman atau bertanya kepada guru. Di samping itu dari hasil wawancara beberapa orang siswa, diperoleh informasi bahwa siswa merasa tertantang dengan soal tes kemampuan pemecahan masalah yang diberikan oleh guru. Siswa tidak menyerah dan berusaha untuk memecahkan masalah yang diberikan. Artinya siswa mempunyai kendali yang kuat.

Selanjutnya pada aspek origin yaitu kemampuan siswa dalam menempatkan perasaan dirinya dan memandang kesulitan yang terjadi bersumber dari dirinya seorang atau faktor-faktor lain di luar dirinya, diperoleh rataan siswa kelas ITCRA adalah sebesar 16,05 atau 64,19\% dari skor maksimum ideal dan kelas konvensional 15,68 atau $62,33 \%$ dari skor maksimum ideal 24,99 . Terlihat perbedaan yang sangat kecil, yaitu sebesar 0,46. Artinya adversity quotient matematis siswa kelas ITCRA relatif sama dengan kelas konvensional pada aspek origin. Sedangkan pada aspek ownership yang meliputi aspek sejauh manakah siswa mengakui akibat kesulitan dan sejauh manakah siswa mampu belajar atas kesalahan yang dilakukannya, diperoleh rataan skor kelas ITCRA sebesar 24,71 atau $66,48 \%$ dari skor maksimum ideal dan kelas konvensional 21,74 atau $58,50 \%$ dari skor maksimum ideal 37,16. Terdapat perbedaan sebesar 2,97, artinya kemampuan siswa kelas ITCRA dalam hal mengakui akibat kesulitan yang dialami dan belajar atas kesalahan tersebut yang dilakukan, lebih baik daripada siswa kelas konvensional.

Berdasarkan hasil wawancara, diperoleh informasi bahwa siswa cenderung mempersalahkan dirinya sebagai penyebab tidak bisa mengerjakan soal yang diberikan guru. Namun, siswa tidak berlebihan menyalahkan dirinya sebagai penyebab kesulitan, siswa tidak merasa kemampuan matematikanya lemah hanya saja usaha yang dilakukannya kurang sehingga kesulitan memecahkan soal yang diberikan guru. Siswa merasa kesulitan yang diperoleh dikarenakan malas mengulang pelajaran di rumah, dan terkadang tidak fokus saat belajar matematika. Dengan perasaan merasa bersalah tersebut, siswa merasa harus lebih rajin lagi belajar agar tidak mendapati kesulitan yang sama pada ulangan-ulangan berikutnya. Dari hasil wawancara tersebut juga diperoleh informasi bahwa saat siswa kesulitan memahami pelajaran matematika atau memecahkan soal matematika saat pembelajaran matematika, siswa berusaha 
bertanya kepada guru di sekolah, guru les, atau bertanya kepada teman yang memahaminya. Hal ini memperlihatkan keinginan siswa untuk memperbaiki kesalahannya.

Pada aspek reach yaitu kemampuan siswa dalam membatasi masalah agar tidak menjangkau bidang-bidang lain dalam kehidupannya, diperoleh rataan skor siswa kelas ITCRA yaitu 9,26 atau 70,27\% dari skor maksimum ideal dan kelas konvensional 8,30 atau $62,95 \%$ dari skor maksimum ideal 13,18. Hanya terdapat sedikit perbedaan, yaitu sebesar 0,96. Artinya adversity quotient matematis siswa kelas ITCRA dan kelas konvensional pada aspek reach relatif sama. Berdasarkan hasil wawancara, kesulitan siswa dalam pembelajaran matematika tidak mempengaruhi semangat belajarnya dan tidak juga membuat siswa berpikir untuk tidak menyenangi matematika. Soal pemecahan masalah yang diberikan oleh guru membuat siswa tertantang, penasaran, dan semangat untuk memecahkannya. Hal ini juga terlihat dari hasil pengamatan, bahwa siswa semangat dan antusias mengerjakan soal pada LKS.

Selanjutnya aspek endurance, yaitu kemampuan siswa dalam memandang berapa lama kesulitan dan penyebab kesulitan akan berlangsung yang meliputi apakah seseorang cenderung untuk memandang masalah tersebut terjadi secara permanen dan berkelanjutan atau hanya dalam waktu yang singkat saja. Rataan siswa kelas ITCRA pada aspek endurance ini adalah sebesar 13,10 atau $80,17 \%$ dari skor maksimum ideal dan kelas konvensional 10,80 atau $66,11 \%$ dari skor maksimum ideal 16,34 Artinya adversity quotient matematis siswa dalam aspek endurance pada siswa kelas ITCRA lebih baik daripada siswa kelas konvensional. Hasil ini sesuai dengan pengamatan yang dilakukan selama proses pembelajaran, aktivitas siswa saat menghadapi kesulitan, secara bertahap pada tiap pertemuan siswa tidak berpangku tangan pada siswa lain yang lebih mampu, siswa secara individu mencoba menyelesaikan soal yang diberikan. Artinya siswa memandang bahwa kesulitan yang dihadapi hanya bersifat sementara.

Berdasarkan uraian di atas, dapat disimpulkan bahwa secara umum adversity quotient siswa yang memperoleh pembelajaran inkuiri terbimbing dengan pendekatan concreterepresentational-abstract (ITCRA) lebih baik daripada siswa yang memperoleh pembelajaran konvensional, baik dari aspek control, origin, ownership, reach, maupuan endurance. Hal ini disebabkan di dalam pembelajaran ITCRA terdapat aktivitas pembelajaran yang memungkinkan siswa untuk menerapkan langkah-langkah pemecahan masalah dan berkomunikasi secara aktif melalui kegiatan belajar matematika mandiri maupun berkelompok. Selain itu juga, dalam pembelajaran ITCRA memuat tugas-tugas yang menantang serta dapat siswa mengambil peran yang lebih besar dalam tanggung jawab belajarnya. Sebagaimana yang dinyatakan oleh Rifameutia (Hawadi, 2004), salah satu solusi untuk meningkatkan AQ setiap siswa yakni melalui pendekatan pembelajaran yang memberikan kesempatan kepada siswa untuk selalu memecahkan masalah dan bersifat menantang.

Stoltz (2000) mengatakan bahwa adversity quotient seseorang dapat ditingkatkan dengan melakukan aktivitas listen yaitu mendengarkan 
respon-respon terhadap kesulitan, explore yaitu memahami kesulitan serta konsekuensi dari kesulitan yang dihadapi, analysis yaitu menelusuri bagaimana kendalinya terhadap kesulitan yang dihadapinya, dan apakah kesulitan tersebut harus lebih lama dari semestinya, dan do yaitu mengambil tindakan saat dalam menghadapi kesulitan. Pada pembelajaran ITCRA memungkinkan siswa melakukan hal-hal tersebut, karena dalam pembelajaran inkuiri terbimbing siswa dapat mengutarakan kesulitannya saat pembelajaran kepada guru maupun kepada teman di kelompoknya, sehingga siswa dapat mengatasi kesulitan yang dihadapinya. Dan juga tetap semangat memecahkan masalah yang diberikan oleh guru. Selain itu, dengan berdiskusi untuk memecahkan masalah siswa dapat mengidentifikasi penyebab kesulitan yang ia hadapi serta menemukan solusi atau cara yang harus dilakukannya agar tidak menemukan kesulitan yang sama.

Untuk mengetahui deskripsi tingkat adversity quotient matematis siswa, maka perhitungannya didasarkan pada skor hipotetik. Digunakannya skor hipotetik karena alat ukur adversity quotient matematis ini belum mempunyai aturan yang jelas mengenai pengkategorian tingkat adversity quotient matematis. Dari hasil skor hipotetik, kemudian dikelompokkan menjadi tiga kategori yaitu kategori tinggi, sedang, dan rendah (Sudijono dalam Sakrani, 2014). Hasil selengkapnya dari perhitungan dapat dilihat pada uraian berikut:

1) Menghitung nilai mean $(\mu)$ dan standar deviasi $(\sigma)$ pada skala adversity quotient matematis yang digunakan yaitu 28 item.
2) Menghitung mean hipotetik $(\mu)$, dengan rumus:

$$
\begin{gathered}
\mu=\frac{\left(i_{\text {maks }}+i_{\min }\right)}{2} \sum k=\left(\frac{4+1}{2}\right) \cdot 28 \\
=70
\end{gathered}
$$

3) Menghitung standar deviasi hipotetik ( $\sigma)$, dengan rumus:

$$
\begin{gathered}
\sigma=\frac{1}{6}\left(X_{\text {maks }}-X_{\text {min }}\right)=\frac{1}{6}(112-28) \\
=14
\end{gathered}
$$

4) Kategorisasi

Tabel 4. Rumusan Kategori Adversity Quotient Matematis Siswa

\begin{tabular}{lll}
\hline \multicolumn{1}{c}{ Rumusan } & Kategori & \multicolumn{1}{c}{ Kriteria } \\
\hline$X>(\mu+\sigma)$ & Tinggi & $X>84$ \\
$(\mu-\sigma) \leq X \leq(\mu+\sigma)$ & Sedang & $56 \leq X \leq 84$ \\
$X<(\mu-\sigma)$ & Rendah & $X<56$ \\
\hline
\end{tabular}

Berikut adalah Tingkat adversity quotient matematis siswa kelas ITCRA

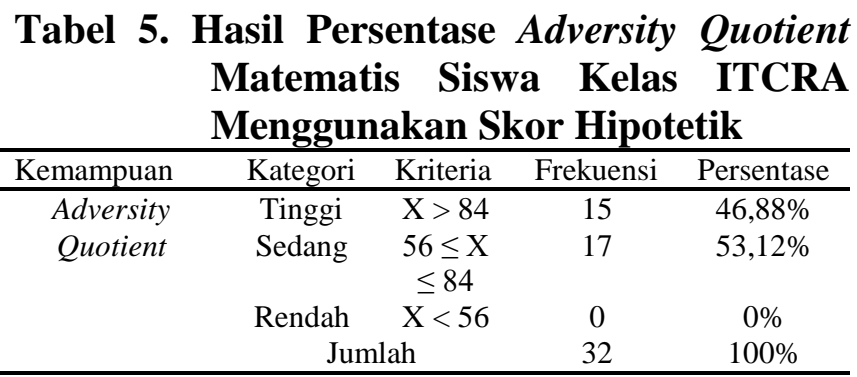

Berdasarkan Tabel 5 di atas, secara umum dapat diketahui bahwa pada kelas ITCRA terdapat 46,88\% siswa dengan tingkat adversity quotient matematis bahwa tinggi dan 53,12\% siswa dengan tingkat adversity quotient matematis sedang, serta tidak ada siswa yang termasuk pada tingkat adversity quotient matematis rendah. Selanjutnya, berikut Tingkat adversity quotient matematis siswa kelas konvensional. 
Tabel 6. Hasil Persentase Adversity Quotient Matematis Siswa Kelas Konvensional Menggunakan Skor Hipotetik

\begin{tabular}{ccccc}
\hline Kemampuan & Kategori & Kriteria & Frekuensi & Persentase \\
\hline Adversity & Tinggi & $\mathrm{X}>84$ & 4 & $11,76 \%$ \\
Quotient & Sedang & $56 \leq \mathrm{X}$ & 30 & $88,24 \%$ \\
& & $\leq 84$ & & \\
& Rendah & $\mathrm{X}<56$ & 0 & $0 \%$ \\
& Jumlah & 34 & $100 \%$ \\
\hline
\end{tabular}

Berdasarkan Tabel 6 di atas, secara umum dapat diketahui bahwa pada kelas konvensional terdapat $11,76 \%$ siswa dengan tingkat adversity quotient matematis bahwa tinggi dan $88,24 \%$ siswa dengan tingkat adversity quotient matematis sedang, serta tidak ada siswa yang termasuk pada tingkat adversity quotient matematis rendah.

Salah satu temuan dalam penelitian ini memperlihatkan bahwa ketika menghadapi masalah dalam tugas belajarnya, jumlah siswa kelas ITCRA yang tergolong campers dan climbers hampir sama, dan tidak ada siswa yang tergolong quitters. Ketika siswa diberikan permasalahan matematis, siswa cenderung merespon positif untuk menyelesaikan soal sebagai tantangan. Mereka mampu mengintegrasi persepsi atau pengalaman barunya ke dalam skema yang ada dipikirannya, sehingga siswa terus berupaya dengan mengerahkan segala kemampuannya mencari penyelesaian permasalahan matematika yang diberikan.

Pada siswa yang tergolong campers, apabila saat memecahkan masalah mereka belum juga menemukan titik akhir penyelesaian permasalahan, pada akhirnya mereka menyerah dan meminta siswa yang tergolong climbers untuk menyelesaikannya. Siswa yang tergolong campers ini akan menunggu jawaban dari siswa yang tergolong climbers karena menganggap usaha yang dilakukannya untuk memecahkan masalah yang diberikan sudah cukup dan merasa tidak bisa juga memecahkannya. Selain itu, setelah menemukan berbagai kesulitan pada saat perjalanannya menuju solusi dari permasalahan, siswa campers cenderung berhenti dan siswa merasa tidak akan menemukan solusi akhir dikarenakan menganggap masalah ini terlalu sulit dari yang dibayangkannya, sehingga siswa lebih memilih menunggu jawaban dari siswa climbers atau menunggu proses pembahasan bersama di kelas.

\section{SIMPULAN DAN SARAN}

\section{Simpulan}

Terdapat perbedaan adversity quotient matematis siswa yang memperoleh pembelajaran ITCRA dengan siswa yang memperoleh pembelajaran konvensional. Hal ini diperkuat dengan temuan bahwa pembelajaran ITCRA memberikan kesempatan lebih banyak kepada siswa untuk berlatih menghadapi dan mengatasi kesulitan dalam memecahkan masalah dengan berdiskusi dan berbagi strategi pemecahan masalah dalam kelompoknya.

\section{Saran}

Guru disarankan membiasakan siswa dengan pembelajaran yang berbasis masalah sehingga siswa terampil dalam memecahkan masalah dan kecerdasan adversity quotient siswa dapat berkembang, salah satunya adalah pembelajaran ITCRA. 


\section{REFERENSI}

Abidin, Y. (2014). Desain sistem pembelajaran dalam konteks Kurikulum 2013. Bandung: PT Refika Aditama.

Dahlan, J.A. \& Dadang, J. (2011). Analisis representasi matematik siswa sekolah dasar dalam penyelesaian masalah matematika kontekstual. Jurnal Pengajaran MIPA Vol. 16 No. 1. Hlm. 1-11.

Flores, M. M. (2010). Using the concreterepresentational-abstract sequence to teach substraction with regrouping to students at risk for failure. Journal remedial and Special education Vol. 31 Hammil Institute on Disabilities.

Guler, G., Ciltas, A. (2011). The visual representation usage level of mathematics teachers and students in solving verbal problem. International Journal of Humanities and Social Science Vol. 1 No. 11. Ataturk University, Turkey.

Hawadi, R.A. (2004). Kiat-kiat memantapkan adversity quotient siswa akseleran, dalam akselerasi $A-Z$ informasi program percepatan belajar dan anak berbakat intelektual. Jakarta: PT Gramedia Widiasarana Indonesia.
Matthew, B.M., Kenneth, I.O. (2013). A study on the effects of guided inkuiri teaching method on students achievement in logic. International Researcher Volume No. 2 Issue no. 1 .

OECD. (2013). PISA 2012 assessment and analytical framework: mathematics, reading, science, problem solving and financial literacy. Paris: OECD Publishing.

Stoltz, P. G. (2000). Adversity quotient, mengubah hambatan menjadi peluang. Jakarta: Terjemahan, PT Gramedia Widiasarana Indonesia.

Witzel, B. S. (2005). Using CRA to teach algebra to students with math difficulties in inclusive settings. Learning Disabilities : $A$ Contemporary Journal, 3(2), 49-60.

Yuliawaty, L. (2011). Pembelajaran matematika dengan pendekatan concrete representational abstract (CRA) untuk meningkatkan kemampuan pemahaman dan pemecahan masalah matematik siswa SMP. (Tesis). Sekolah Pascasarjana, Universitas Pendidikan Indonesia, Bandung. 